\title{
Penerapan Gaya Modern Urban pada Interior Sebuah Perusahaan Pengembang Bisnis Properti
}

\author{
Ima Nur Lailatul Faridah dan Nanik Rachmaniyah \\ Departemen Desain Interior, Fakultas Arsitektur Desain dan Perencanaan, \\ Institut Teknologi Sepuluh Nopember (ITS) \\ e-mail: imalfaridah@gmail.com, rachmaniyah@gmail.com
}

\begin{abstract}
Abstrak-Pertumbuhan pasar properti yang pesat memicu persaingan antar perusahaan pengembang properti. Masingmasing perusahaan berlomba meningkatkan kualitas untuk menarik minat pasar salah satunya di bidang interior. Interior perusahaan selain terlihat menarik dan rapi juga dapat mencerminkan identitas perusahaan. Konsep interior modern urban adalah paduan konsep yang menonjolkan perusahaan dengan karakter profesional, kompetitif, dan inovatif. Konsep modern mewakili sifat kekinian. Konsep urban mewakili gaya hidup dengan aktivitas tinggi, serba cepat, dan penuh kompetisi. Aplikasi konsep modern urban pada interior perusahaan pengembang properti meliputi berbagai aspek mulai dari dinding, lantai, plafon, furnitur, dan elemen estetis. Penerapan konsep modern menggunakan konsep glossy dan simple geometric. Penerapan konsep urban menggunakan konsep mobile dan unfinish.
\end{abstract}

Kata Kunci-desain interior, modern, perusahaan properti, urban.

\section{PENDAHULUAN}

$\mathrm{S}_{\mathrm{p}}^{\mathrm{E}}$ EKTOR datangnya properti dinilai memiliki peranan penting dalam menyumbang pertumbuhan perekonomian nasional. Bahkan, sektor ini diyakini akan mampu menjadi tolok ukur pertumbuhana ekonomi suatu saat nanti. Pada 2017 lalu, nilai kapitalisasi 35 persen saham dari 46 grup properti yang tercatat di Bursa Efek Indonesia mencapai Rp 280 triliun. Bila nilai itu diakumulasikan hingga 100 persen, maka jumlahnya diprediksi dapat mencapai Rp 840 triliun.

Perkembangan ini memicu persaingan antar pengembang bisnis properti. Salah satunya, persaingan dapat dilihat dengan mengamati kualitas interior perusahaan. Interior perusahaan sebaiknya tidak hanya terlihat menarik dan rapi tapi juga dapat mencerminkan identitas perusahaan. Interior konsep modern urban merupakan paduan konsep interior yang dapat menonjolkan perusahaan dengan karakter profesional, kompetitif, dan inovatif. Hal ini karena konsep modern representasi sifat kekinian dan konsep urban representasi gaya hidup dengan aktivitas tinggi, serba cepat, dan penuh kompetisi.

Penerapan konsep modern urban pada interior sebuah perusahaan pengembang properti di Jawa Timur meliputi berbagai aspek mulai dari dinding, lantai, plafon, furnitur, dan elemen estetis.

Terdapat masalah yang menjadi topik utama perancangan yaitu bagaimana mendapat konsep modern urban ke dalam interior yang berkesesuaian dengan identitas perusahaan. Berdasarkan permasalahan tersebut, tujuan perancangan adalah mengetahui cara menerapkan tema modern urban secara representatif terhadap elemen interior. Manfaat perancangan adalah sebagai referensi yang dapat menginspirasi renovasi interior kantor terutama perusahaan properti.

\section{KAJIAN LITERATUR}

Kantor adalah balai atau gedung tempat menulis atau mengurus suatu pekerjaan [1]. Kantor juga adalah tempat dalam suatu badan usaha melaksanakan pekerjaan administratif (tata usaha) yang dapat dilakukan dengan mesin atau tangan [2]. Menurut Glen W. Howard, kantor adalah pusat dari kegiatan administrasi (tata usaha) dan berperan sebagai suatu kamar kerja dan belajar, suatu ruang rapat, suatu tempat perundingan, suatu pusat penerangan, suatu pusat pemberian pelayanan, suatu kamar untuk berkas-berkas, suatu ruang perjamuan dan seringkali suatu lambang dari kedudukan mendekatkan pelayanan kepada masyarakat [3].

\section{A. Sistem Penataan Kantor}

Menurut Francis dkk, pembagian ruang pada suatu bangunan kantor dapat dikelompokkan menjadi empat yaitu cellular, group space, open plan, dan landscape [4].

Penataan ruang cellular (a) merupakan penataan ruang dalam bentuk tradisional dengan koridor sempit dengan banyak ruang di kanan kiri. Kapasitas tiap kamar biasanya lima orang dengan kedalaman ruang 12 meter. Penataan ruang group space (b) merupakan perkembangan bentuk cellular, dengan ruang yang lebih luas dan fleksibel. Jarak koridor ke luar $\pm 15-20 \mathrm{~m}$. Bentuk penataan open plan (c) adalah bentuk penataan geometri yang kaku, layout ruangan sangat luas, susunan ruang fleksibel menurut kebutuhan pemakai, dan berdasarkan pembagian sub definisi dan ruang kerja. Batasbatas sirkulasi daerah kerja pada penataan landscape (d) memberi identitas kelompok. Tirai, tanaman, lemari, dan furnitur membentuk jalur sirkulasi.

Lingkungan fisik memiliki pengaruh sangat besar kepada kepuasan kerja. Persepsi privasi dan suara adalah faktor spesifik yang memiliki efek pada kepuasan bekerja dan kepuasan pada umumnya di kalangan pekerja. Menurut sebuah studi kasus, 469 karyawan di 26 perusahaan berbeda di Stockholm-Swedia, menilai kepuasan mereka terhadap lingkungan kantor dalam tujuh tipe kantor yang berbeda. Hasil studi ini mengindikasi bahwa tipe kantor terbuka, serta tipe kantor berkamar, sebenarnya dapat memenuhi kebutuhan privasi. Hasil positif ditunjukkan oleh karyawan pada tipe 
kantor fleksibel karena mereka dapat mengontrol ruang kerja sesuai kebutuhan pengguna.

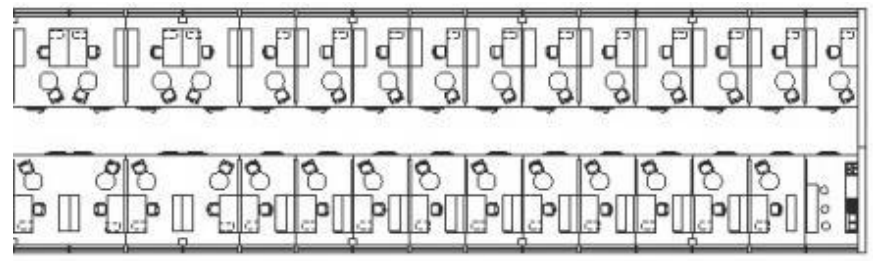

(a)

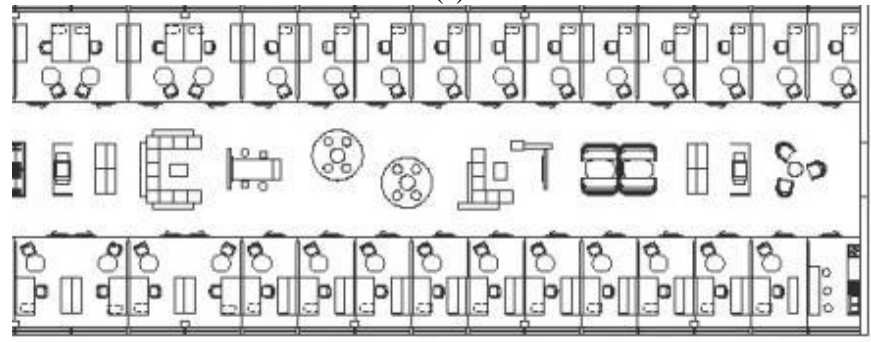

(b)

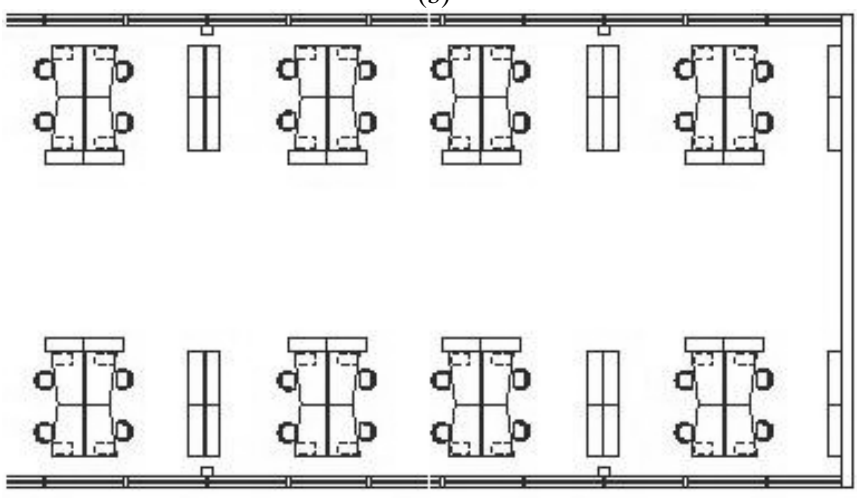

(c)

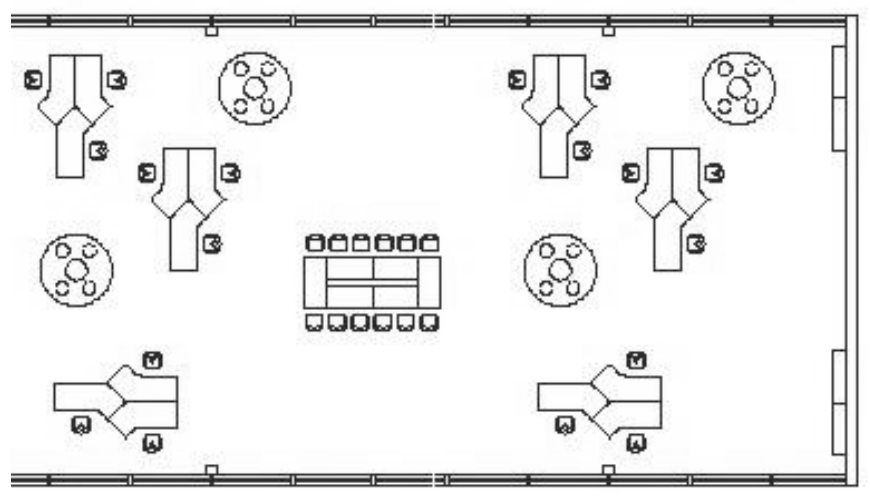

(d)

Gambar 1. Penataan ruang kantor berdasarkan Planning Office Space (1976).

\section{B. Penerapan Identitas Perusahaan pada Interior}

Penerapan branding pada interior akan maksimal apabila menerapkan ketiga aspek interior branding secara seimbang. Tolok ukur interior branding berupa: clear vision, unique story, dan energy [5].

Aspek clear vision adalah aspek yang menunjang kelancaran aktivitas seperti dalam hal pembagian ruang dan signage. Aspek ini berkaitan dengan kejelasan identitas perusahaan. Memperjelas identitas perusahaan secara langsung atau tidak langsung dapat memberitahu pengguna bagaimana perusahaan bergerak dalam bidang masing-masing.

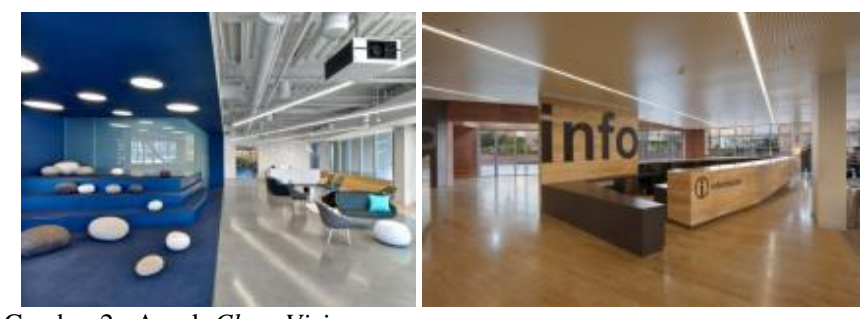

Gambar 2. Aspek Clear Vision.

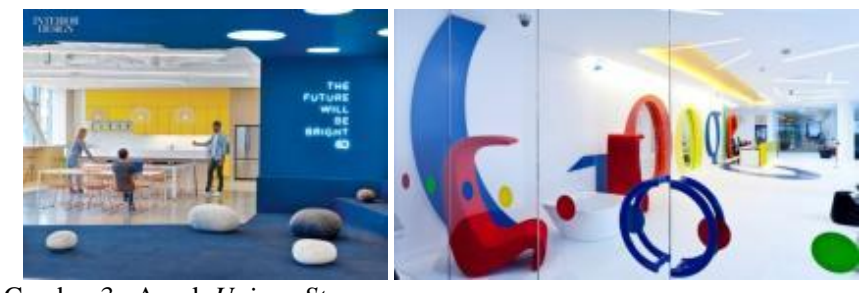

Gambar 3. Aspek Unique Story.

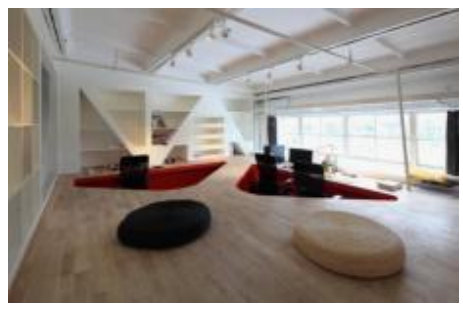

Gambar 4. Aspek Energy.

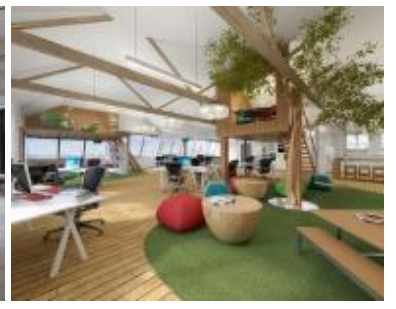

Aspek unique story adalah aspek dimana cerita/pesan unik sebuah ruang dapat tersampaikan kepada pengunjung melalui desain interior. Desain interior dapat berupa perkembangan logo, visi misi perusahaan, bidang jasa, produk, bagaimana perusahaan beroperasi, dll.

Aspek energy adalah aspek yang berkaitan dengan segala sesuatu yang mempengaruhi first impression pengunjung. Aspek ini meliputi keindahan visual, kualitas, sistem pengkondisian, dan fasilitas ruang yang menarik perhatian dan menunjang kenyamanan pengunjung

\section{Tema Modern}

Langgam modern diketahui telah berkembang lebih kurang setengah abad, berawal kira-kira tahun 1920 hingga 1960, diawali dengan munculnya Revolusi Industri (1760-1863) di Inggris. Revolusi Industri telah membawa perubahan besar dalam bidang teknologi, sosial, dan kebudayaan. Demikian juga dalam bidang arsitektur dan desain yang selalu dipengaruhi oleh perubahan dalam masyarakat. Langgam modern setahap demi setahap menghapuskan ornamenornamen dan dekorasi yang banyak terdapat pada era pramodern dan menggantinya dengan bentuk-bentuk geometris. Bentuk-bentuk geometris yang sederhana menjadi ciri rupa arsitektur langgam modern. Setelah berjalan beberapa lama, langgam modern dapat disimpulkan mempunyai ciri sebagai berikut:

1. Terlihat mempunyai keseragaman dalam penggunaan skala manusia.

2. Bangunan bersifat fungsional, artinya sebuah bangunan dapat mencapai tujuan semaksimal mungkin, bila sesuai dengan fungsinya. 
3. Bentuk bangunan sederhana dan bersih yang berasal dari seni kubisme dan abstrak yang terdiri dari bentuk-bentuk aneh, tetapi intinya adalah bentuk segi empat.

4. Konstruksi diperlihatkan.

5. Penggunaan bahan pabrik yang ditampakkan secara jujur, tidak diberi ornamen atau tempelan - tempelan dekorasi.

6. Interior dan eksterior bangunan terdiri dari garis-garis vertikal dan horisontal

7. Konsep open plan membagi dalam elemen-elemen struktur primer dan sekunder, dengan tujuan untuk mendapatkan fleksibilitas dan variasi di dalam bangunan [6].

Ciri-ciri tema modern paling sesuai untuk diterapkan pada interior kantor adalah bentukan segi empat, terdiri dari garisgaris vertikal horisontal (geometris), dan menghindari penggunaan ornamen (simple). Konsep simple-geometric mudah dijumpai pada bentuk ruang dan furnitur dengan ciri utama terlihat dari bentukan merupakan permainan bentuk segi empat. Penerapan non ornamen dapat berupa penggunaan material polos pada bentuk ruang dan furnitur.

Pemilihan warna dan tekstur material pabrik menonjolkan tema modern karena umumnya material polos tanpa ornanmen. Material berupa besi, baja, tembaga, aluminium, dan lain-lain. Dari contoh tersebut, warna monokrom dan sifat glossy merupakan ciri-ciri paling umum dimiliki material.

\section{Tema Urban}

Menurut Carr dkk, desain urban termasuk di dalamnya membahas tentang ruang terbuka. Ruang terbuka (khususnya di perkotaan) merupakan sebuah wadah yang biasa digunakan masyarakat untuk melakukan kegiatan-kegiatan dan ritual yang mengeratkan hubungan suatu komunitas [7]. Menurut Kevin Lynch, desain urban berhubungan dengan 3 elemen; pola aktivitas, pola sirkulasi, dan pola dari bentuk mendukungnya [8]. Poin-poin tersebut menunjukkan bahwa ketiganya saling berkesinambungan. Masyarakat urban dengan aktivitas tinggi membutuhkan desain yang dapat menjawab permasalahan tersebut. Solusi sebuah interior dengan pergerakan tinggi adalah dengan menjadikan elemen-elemen di dalamnya ikut bergerak (mobile).

Dalam perkembangan desain, interior yang menunjang aktivitas tinggi menjadi filosofi dasar tema urban. Material unfinish memberi sentuhan seolah interior dikerjakan setengah selesai karena ruangan segera digunakan. Material unfinish dapat berupa dinding bata, lantai dan dinding semen, furnitur unfinish, permukaan kayu dengan finishing kasar, dll

Secara keseluruhan, langgam modern paling sesuai untuk diterapkan pada interior kantor adalah; ruang terbuka, konsep mobile, dan penggunaan material unfinish.

\section{URAIAN PENELITIAN}

Proses riset dan teknik pengumpulan data menggunakan studi literatur, observasi, dan kuesioner.

\section{A. Studi Literatur}

Berdasarkan studi literatur, perpaduan konsep interior modern urban dapat mencerminkan perusahaan yang memiliki karakter profesional, kompetitif dan inovatif. Bentukan kaku konsep modern mampu mencerminkan ciri profesionalisme. Filosofi konsep urban cocok dengan ciri inovatif dan kompetitif perusahaan. Data yang didapatkan adalah tinjauan tentang sistem penataan kantor, tema modern, tema urban, desain interior modern, dan desain interior urban. menggunakannya. observasi, dan kuesioner.

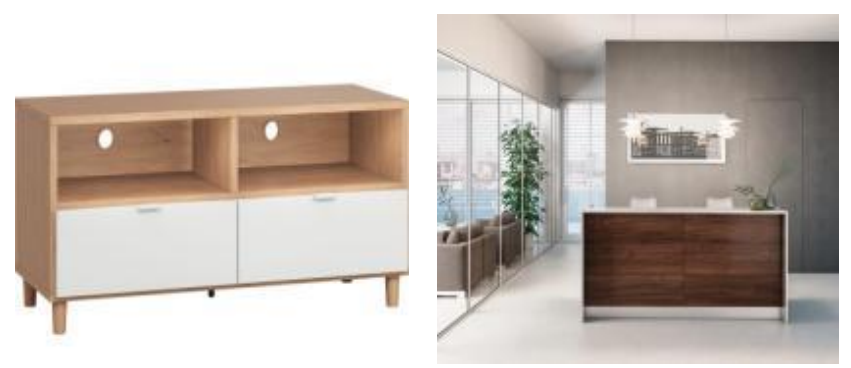

Gambar 5. Bentukan Furnitur Merupakan Permainan Bentuk Segi Empat.

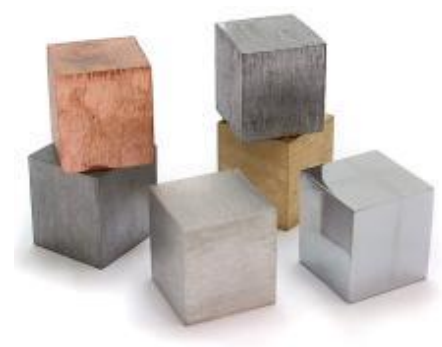

Gambar 6. Contoh Material Fabrikasi.

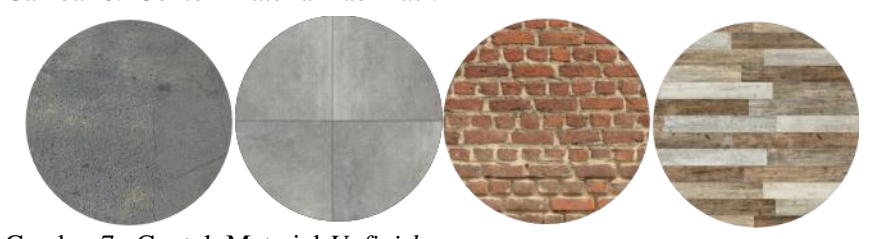

Gambar 7. Contoh Material Unfinish.

\section{B. Observasi}

Observasi dilakukan untuk mengamati interior eksisting perusahaan dan mengamati aktivitas pada ruang publik dan privat. Berdasarkan observasi yang dilakukan, ruangan yang sering digunakan adalah ruang, rapat, area kerja, kafetaria, lobi dan area resepsionis. Observasi juga menunjukkan kualitas elemen interior seperti pemilihan furnitur akan menunjang interior perusahaan dengan karakter aktif bersaing. Selain itu, ruangan publik dengan fasilitas lengkap dan desain interior yang fungsional menambah minat pengunjung untuk menggunakannya.

\section{Kuesioner}

Kuesioner dilakukan untuk mencari data tentang kebutuhan pengguna perusahaan peengembang bisnis properti dan disesuaikan dengan konsep yang digunakan. Kuisioner dibagikan secara online dan diisi oleh 61 responden. Berikut adalah hasil kuisioner yang telah dibuat:

1) Interior kantor yang mencerminkan perusahaan profesional dengan pelayanan prima.

Konsep modern $(51,2 \%)$, konsep futuristik $(25,6 \%)$, konsep urban dan minimalis $(11,6 \%)$. 
2) Interior kantor yang mencerminkan perusahaan Kompetitif

Open plan flex $(32,6 \%)$, open plan $(30,2 \%)$, group space $(27,9 \%)$, traditional open plan $(9,3 \%)$.

3) Interior kantor yang mencerminkan perusahaan Inovatif

Unik saat bekerja $(44,2 \%)$, luas dan leluasa $(32,6 \%)$, memudahkan komunikasi $(18,6 \%)$, privatif $(4,7 \%)$.
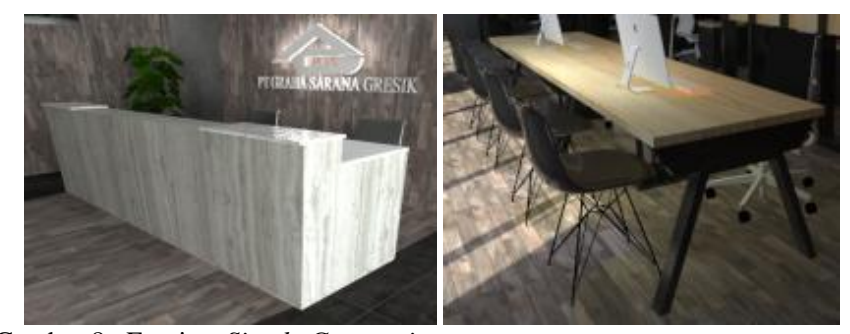

Gambar 8. Furnitur Simple Geometric.

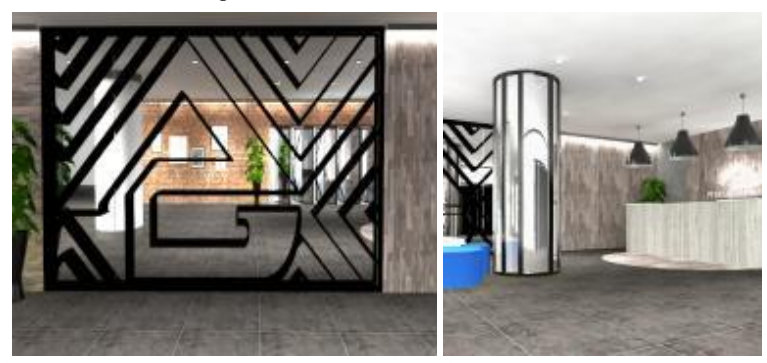

Gambar 9. Contoh Penggunaan Finishing Glossy.

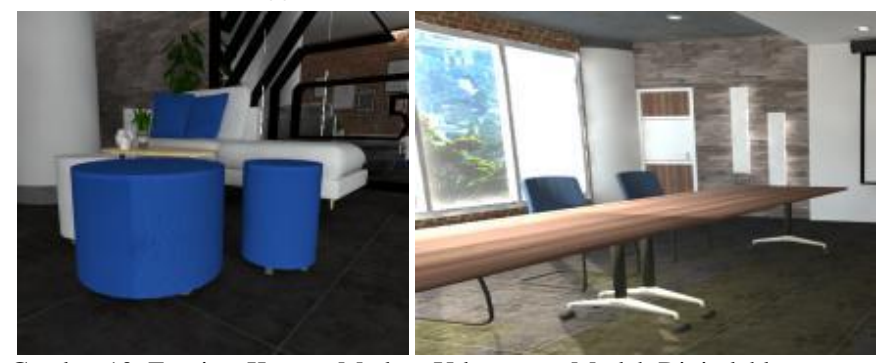

Gambar 10. Furnitur Konsep Modern Urban yang Mudah Dipindahkan.

\section{APLIKASI KONSEP MODERN URBAN}

Konsep interior modern urban cocok untuk sebuah perusahaan yang kompetitif dan bersifat kekinian. Penerapan tema modern urban yang representatif adalah dengan mengaplikasikan karakter-karakter tema modern urban yaitu; penggunaan konsep simple geometric, penggunaan warna monokrom dan finishing glossy, penggunaan konsep mobile pada furnitur, dan material unfinish.

\section{A. Konsep Simple Geometric}

Penerapan konsep ini dapat dengan jelas terlihat pada furnitur ruangan. Desain furnitur memiliki kontur garis yang tegas dan bentukan yang intinya adalah permainan segi empat.

\section{B. Glossy}

Penggunaan glossy atau finishing untuk menghasilkan permukaan mengkilap ke dalam interior dapat menghasilkan kesan ruang semu sehingga ruangan terlihat lebih luas. Ide-ide finishing glossy dapat diaplikasikan pada elemen-elemen interior yang tidak terduga seperti pada dinding (kiri) dan kolom (b). Penerapan seperti pada gambar mengubah elemen interior menjadi elemen estetis yang representatif.

\section{Furnitur Mobile}

Konsep mobile pada furnitur diilhami dari filosofi tema urban yaitu furnitur yang menunjang aktivitas tinggi di dalamnya. Oleh karena itu, konsep mobile pada furnitur diterapkan melalui pemilihan material ringan, furnitur memiliki roda, dapat dilipat, sehingga mudah diangkat, digeser, dan disimpan di tempat lain. Sehingga apabila sewaktu-waktu ruang beralih fungsi, furnitur dapat dengan mudah dipindahkan. Aktivitas tinggi di dalam ruangan Konsep furnitur mobile

\section{Material Unfinish}

Penerapan material unfinish dapat diaplikasikan dengan mudah ke seluruh elemen interior seperti dinding, plafon, dan lantai. Material unfinish umumnya mampu memberi kesan 'ramai' sehingga tidak membutuhkan banyak elemen estetis lain untuk mengisi ruang.

Material unfinish dinding dapat dihadirkan ke dalam ruang dengan menggunakan bata tempel (kiri), dinding dengan cat semen (tengan), atau dengan stikwood (kanan). Stikwood yang dipilih memiliki motif natural unfinish. Pada tepi atas dinding dapat dilengkapi dengan permainan lampu menggunakan hidden light dengan LED strip untuk mempertegas garis ruang.

Plafon unfinish dapat diterapkan dengan menggunakan cat efek semen. Pada plafon dapat diterapkan zoning atau pembagian ruang. Plafon drop ceiling dan plafon semen dapat mewakili dua area dengan fungsi berbeda. Misalkan, drop ceiling mewakili area untuk duduk sedangkan plafon semen mewakili area untuk sirkulasi.

Lantai unfinish dapat diterapkan dengan menggunakan penutup lantai jenis concrete tile dan plankwood natural unfinish. Paduan dua jenis lantai juga dapat dimanfaatkan untuk zoning. Misalkan, lantai plankwood adalah untuk area resepsionis sedangkan lantai concrete tiles adalah untuk area sirkulasi.

\section{E. Penerapan Identitas Perusahaan}

Penerapan identitas perusahaan ke dalam interior adalah salah satu usaha branding kepada pengguna umum. Interior branding harus dapat menghadirkan ciri perusahaan yang hanya dimiliki oleh perusahaan itu sendiri. Interior branding dapat dilakukan dengan memanfaatkan logo, visi misi, dan warna perusahaan.

Interior branding tidak harus dilakukan dengan sematamata menghadirkan bentuk logo ke dalam ruang. Logo dapat diaplikasikan secara unik dengan cara direpetisi hingga membentuk kesatuan elemen estetis. Elemen estetis dapat dipasang lebar pada elemen interior contohnya dinding.

Ide interior branding pada dinding lainnya dapat berupa penerapan logo pada dinding cermin. Logo dapat terbuat dari material kokoh seperti besi atau kayu. Ide interior branding dapat juga hadir dengan menerapkan warna perusahaan pada furnitur. Furnitur berikut dapat menjadi point of interest karean memiliki warna yang stand-out diantara warna elemen interior yang lain. 


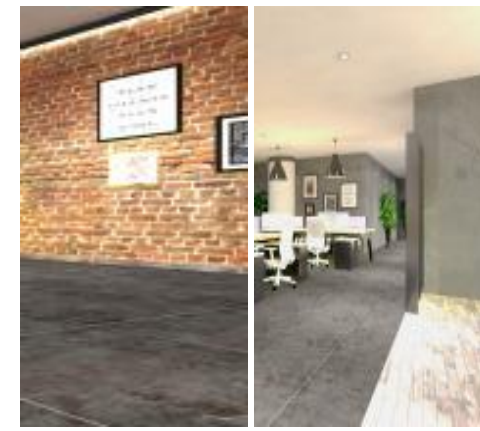

Gambar 11. Dinding Unfinish.
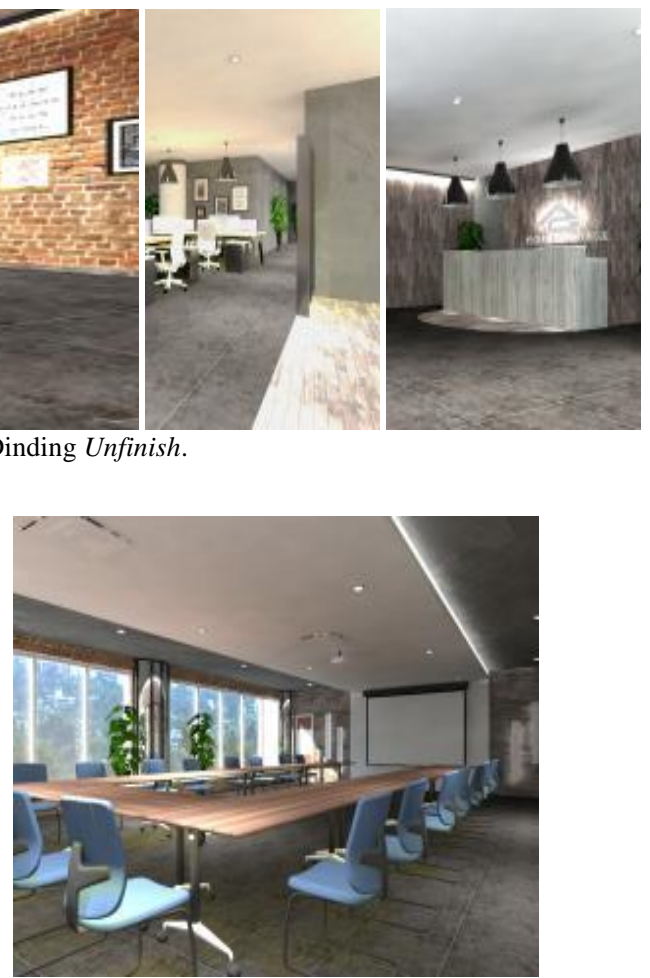

Gambar 12. Plafon Unfinish.

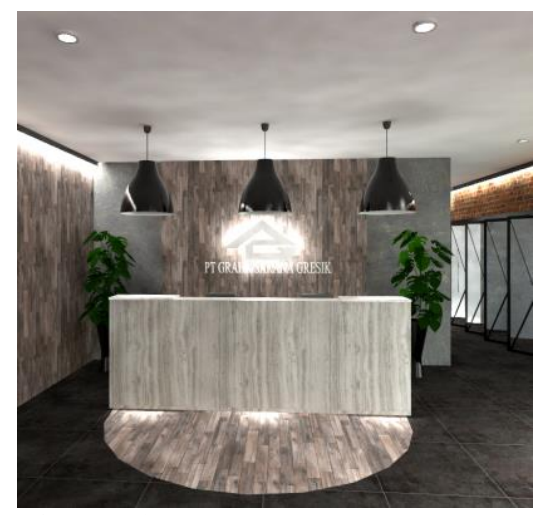

Gambar 13. Lantai Unfinish.

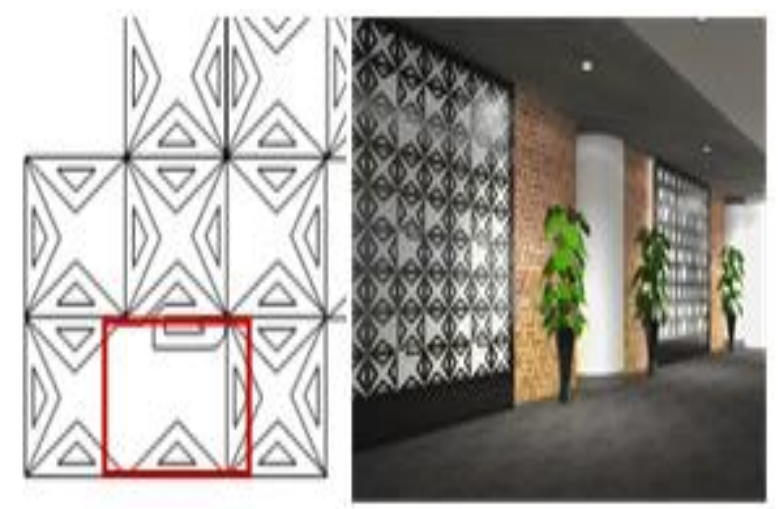

Gambar 14. Logo pada Elemen Estetis Dinding.

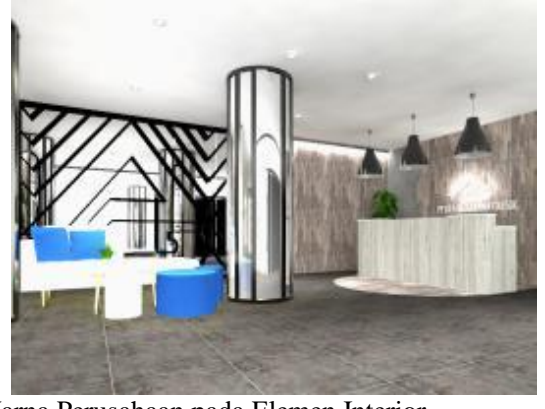

Gambar 15. Warna Perusahaan pada Elemen Interior.

\section{KESIMPULAN/RINGKASAN}

\section{A. Kesimpulan}

Kesimpulan yang dapat diambil adalah sebagai berikut:

1. Konsep modern urban dipilih untuk menonjolkan identitas perusahaan. Tema modern representasi sifat kekinian. Tema urban representasi gaya hidup dengan aktivitas tinggi, serba cepat, dan penuh kompetisi.

2. Konsep modern urban dapat diterapkan dengan menggunakan 4 konsep; simple-geometric, glossy, material unfinish, dan furnitur mobile.

\section{B. Saran}

Saran yang dapat diberikan dari perancangan ini adalah:

1. Selain pengguna utama, desain perlu menimbangkan selera desain pengunjung umum pada area publik.

2. Perlu dilakukan observasi lebih lanjut mencakup aktivitas-aktivitas di dalam perusahaan, baik pengguna utama maupun pengunjung umum.

\section{UCAPAN TERIMA KASIH}

Penulis I. N. L. F. mengucapkan terima kasih kepada Direktorat Pendidikan Tinggi, Departemen Pendidikan dan Kebudayaan Republik Indonesia yang telah memberikan dukungan finansial melalui Beasiswa Bidik Misi tahun 20142018.

\section{DAFTAR PUSTAKA}

[1] P. W.J.S., Kamus Umum Bahasa Indonesia. Jakarta: Balai Pustaka, 2003.

[2] P. Mahieu, De administratieve organisatie der onderne. Standaard Boekhandel, 1948.

[3] T. L. Gie, Ensiklopedia Administrasi. Jakarta: Gunung Agung, 1998.

[4] F. Duffy, C. Cave, and J. Whortington, Planning Office Space. London: The Architecture Press Ltd, 1976.

[5] K. Kuhteubl, Branding + Interior Design, Visibility and Business Strategy for Interior Designers. Schiffer Publishing, Ltd, 2016.

[6] N. Rachmaniyah, "Studi Langgam Desain sebagai Dasar Mendesain Hotel," J. Desain Inter., vol. 1, no. 1, 2016.

[7] dkk. Carr, Stephen, Public Space. USA: Combridge University Press, 1992.

[8] K. Lynch, The Image of the City. Cambridge: MIT Press, 1960. 